\title{
The Origin of Prophetism in the Ancient Near East
}

Author:

Gerda de Villiers ${ }^{1}$

\section{Affiliation: \\ ${ }^{1}$ Department of Old \\ Testament Studies, \\ University of Pretoria, \\ South Africa}

\section{Correspondence to:}

Gerda de Villiers

email:

gerdadev@mweb.co.za

\section{Postal address:}

133b Anderson Street,

Tswane 0181, South Africa

\section{Keywords:}

Prophesy; religion;

witness; revelation;

divination

\section{Dates:}

Received: 31 Jan. 2010

Accepted: 28 May 2010

Published: 08 Oct. 2010

How to cite this article: De Villiers, G., 2010, 'The origin of prophetism in the Ancient Near East', HTS Teologiese Studies/Theological Studies 66(1), Art. \#795, 6 pages. DOI: $10.4102 /$ hts. v66i1.795.

\section{This article is available} at: http://www.hts.org.za

\section{Note:}

This article was initially presented as a paper at the conference on 'Prophetic witness: An appropriate mode of public discourse in democratic societies?' that was held at the University of Pretoria on 26-27 October 2009.

(C) 2010. The Authors. Licensee: OpenJournals Publishing. This work is licensed under the Creative Commons Attribution License.

\section{ABSTRACT}

This article aimed to give an overview of the early attestations to prophecy in the Ancient Near East (ANE) in order to stimulate reflection on what could be understood by 'prophetism'. The most extant sources for prophetic oracles in the ANE were uncovered at the royal archives of Mari and Nineveh, therefore some evidence of these sites has been indicated. Consequently the distinction between 'inductive' and 'non-inductive' forms of divination was also discussed. Furthermore it was questioned whether the critique against ANE-prophecy as 'Heilsprophetie' ('salvation') as opposed to the 'Unheilsprophetie' ('doom') of Old Testament can still be upheld. Finally some notes of caution were raised with regard to the careless appropriation of the term 'prophetism' in the 21st century.

\section{INTRODUCTION}

The terms 'prophet', 'prophecy' and 'prophetism' are often used by religious leaders in the 21st century to encourage believers to take action in order to make the world a better place. But what do prophecy or prophetism really mean? And what is meant by prophet?

A popular opinion is that prophecy foretells the future, however, this meaning is rejected by the vast majority of biblical scholars. Yet, even these theologians will not agree upon a single definition of 'prophetism'. For example, the meaning that the Hebrew Bible attaches to 'prophet' and 'prophetism' is vastly different from what a New Testament scholar or a Missiologist would understand by these terms.

To answer these questions, a convenient starting point may be to look for the origins of the word that appears to be derived from the Greek prophètès - the word which the Septuagint (LXX) used for the translation of the Hebrew nāb $\bar{\imath}^{\prime}$ (cf. Cancik-Kirschbaum 2003:33; Kratz 2006:343). In this sense a prophet is someone who acts as a 'mouthpiece of a god'; a prophet is a human medium who is capable of receiving and transmitting a message from a deity (Nissinen 2004:18-19).

All prophecy has bearing on particular socio-historical circumstances (De Jong 2007:183; Nissinen 2004:23), therefore, this divine-human communication is an event in the present, something that happens in the here and now. Rather than prognostication, prophecy pertains to the disclosure of a divine message which is important for the state of affairs in the present. However, the matter of future cannot be ruled out completely. Prophecies of fortune and doom both follow a particular logic of cause and effect: because of ' $\mathrm{A}$ ', 'B' will follow, thus, some prediction in some way or another is implied. Nevertheless, rather than straightforward descriptions of future events, the element of prediction is something that develops out of a present situation in which the divine plan, relating to matters in the future, is disclosed. Reading the signs in the present, the prophet (or the interpreter of the prophetic message) is able to make calculated projections of what may or may not happen in the (imminent) future.

To sum up: in the most basic sense then, a prophet is someone who delivers a divine message (Kratz 2006:343-344) and prophecy or prophetism pertains to the interpretation of this message. However, the complexity of this statement will unfold in due course.

\section{SOURCES FOR PROPHETISM IN THE ANCIENT NEAR EAST}

Serious questions arise when the evidence for prophetism in the Ancient Near East is examined. In the first place, all extant sources for Ancient Near Eastern prophecy were uncovered by archaeological discovery and consist of written documents - texts - whilst prophetic oracles were most probably delivered orally in the first place (Cancik-Kirschbaum 2003:35; Kratz 2006:344; Nissinen 2003a:4; Van der Toorn 2000:219-221). The obvious problem here pertains to the distance between the spoken word and the written document. Prophecies were not recorded as the oracles were delivered, in fact, a considerable time elapsed between what was spoken and what was written down. With regards to the written documents, it is quite certain that the prophets did not write these words, but that these are the works of the scribes (see the section headed 'The relationship between divination and prophecy' below).

Furthermore, not all prophecies found their way into archives to be preserved for posterity, in fact, the intention may not even have been to keep a record of them at all (Van der Toorn 2000:229) Prophecies, as reflected by the texts, were intended for a particular moment in history as a warning, a reprimand, an encouragement, et cetera. To make matters worse, the sites where prophetic texts were uncovered, and from which inferences regarding Ancient Near Eastern prophecy are drawn, are limited. Although prophetism was a widespread phenomenon across the Ancient Near East, the largest corpus of records comes from mainly two areas: Mari, from the 18th century BCE, and Nineveh, from the first half of the 7th century BCE (cf. Cancik-Kirschbaum 2003:37; De Jong 2007:171; Nissinen 2004:25-26). ${ }^{1}$ Conclusions

1.These are not the only sites. 'Prophetic' documents were uncovered all over the Ancient Near East and Egypt, however, at Mari and Nineveh there happen to be 'collections' which may provide more representative sources of prophecy (cf. Nissinen 2000:237) 
drawn from such evidence are naturally biased, for they reflect only one side of the coin, namely the side reflected by the texts, which happen to be very much scoured off.

\section{The Mari documents ${ }^{2}$}

Mari is a main site in Syria. Most texts from here were recovered in the royal archive and, furthermore, represent a very restricted span of time, that is, they can be dated to the final decade - perhaps less - of the reign of Zimri Lim, c.1775-1761 BCE (Gordon 1995:20; Malamat 1995:52; Nissinen 2004:25). These are mostly first-hand documents which reflect a relative short lapse of time between the oral utterance and its record in writing and thus present a synchronous picture of prophecy. The differences from the prophetic corpus in the Hebrew Bible should be obvious: the Israelite prophets appeared over the course of centuries and their words and deeds had undergone a lengthy and complex literary process of transmission and transcription (Malamat 1995:52-53); consequently, the picture the present is one of diachrony and diversity, even contradiction, a picture that is totally different from the impression reflected by the Mari-oracles.

However, these obvious differences should not obscure the similarities to the prophetic messages from Ancient Israel (Fleming 2004:45; Weinfeld 1995:33). They share the key elements of prophecy: a deity, a message, a prophet and an audience (Nissinen 2004:20). At Mari most prophecies had bearing on royal matters, for example, a god would demand some material goods from the king, like the construction of city gates, buildings, funerary sacrifices, the despatch of valuable objects to various temples, et cetera. Or, the king's (Zimri Lim's) safety would be at stake and he is warned about conspirators at home and enemies abroad (Hammurabi) (see Malamat 1995:53-54). Thus, although one should be cautious to draw direct links between prophecy in Ancient Israel and Mari, the phenomenon is common and its early manifestations are attested in 17 th century Mari.

\section{The Nineveh documents ${ }^{3}$}

The Assyrian prophecies date to the reigns of the Kings Esarhaddon (681-669 BCE) and Ashurbanipal (669-631 BCE), thus more or less co-inciding with the time of Kings Manasseh and Josiah of Judah (De Jong 2007:171; Nissinen 2004:26). Oracles that resemble the examples at Mari are in the form of letters or reports and also pertain mostly to royal matters. The legitimacy of the king is one of the most prominent issues and prophetic oracles are addressed to either the king, the crown prince, the king's mother, even a rebel or a substitute king (De Jong 2007:183). Oracles may also contain demands of a deity, or promise the annihilation of the enemies of the king. These oracles always reflect particular historical situations. Typical introductory formulas are: anāku (' $\left.\mathrm{I}^{\prime}\right)$ followed by the name of the deity, for example, Ištar, and the message, or, abutu ('a word') from, say, Ištar and the message. Often the recipient is encouraged by lā tapalla $h$ ('do not fear!') $)^{4}$

However, there are other collections of prophetic texts which attest to some literary elaboration by a scribe. ${ }^{5}$

Apparently these texts had no oral background but were intended as literary compositions from the outset, thus indicating 'the transition from prophecy to literature in 7th-centuary Assyria' (De Jong 2007:186) and are closer to the kind of prophecy recorded in the Hebrew Bible. Some texts do predict political

\section{For a translation of the Mari Letters and other documents, see Nissinen (2003a:13} 92)

3.For a translation of the Nineveh Oracles and other New Assyrian documents, see Nissinen (2003a:97-175)

4.See also Weinfeld (1995:37).

5.De Jong (2007:172) differs from Parpola's simple distinction between first-hand reports and second-hand compilations on reports. $\mathrm{He}$ hints at an element of Fortschreibung [continuous writing] in these Neo-Assyrian prophecies, limited as their time-span may be. events in the near future as revealed by the gods, however, these predictions should be regarded as vaticinia ex eventu - that is, projected backwards after they had happened. Other texts are only vague predictions of future political events and cover a broad time-span without mentioning the names of the rulers these may be termed 'pseudo predictions' (De Jong 2007:187). Nevertheless, these texts also betray a particular interest or agenda. They appear to be general, for example, by emphasising general attributes of the ideal ruler: one who defeats his enemies, who restores the cult and who cares for the well-being of his subjects. Hereby they actually disclose a particular situation and aim to justify of glorify the reign of a specific king.

The above discussion indicated that most prophetic oracles were found in the royal archives (cf. De Jong 2007:183; also Malamat 1995:54). The close relationship between kingship and prophecy has often been stressed, and rightly so, therefore it would be correct to infer that prophecy was important to the monarchy, but irresponsible to state that all prophecy concerned the king and affairs of the state. There may have been other prophecies as well which were either not recorded, or simply lost. Furthermore, royal prophecies are never without an agenda. Most of these prophecies aim to legitimise the ruling dynasty (cf. also Kratz 2006:344), an observation which immediately points to the conclusion that prophecy was a powerful medium for political propaganda. Those texts found in the royal archives are anything but objective value-free recordings of prophetic utterances! Prophecies, as revealed by the extant sources, are heavily laden with an imperial ideology of a particular historical era. Dealing with the available sources, one should once again remember that the evidence reflects a biased picture.

\section{PROPHECY AND DIVINATION}

Earlier scholars drew a distinction between 'divination' and 'prophecy', thereby aiming to distinguish between inductive and non-inductive measures that would separate the diviners from the prophets (cf. Nissinen 2004:21). Diviners make use of inductive measures and technical operations to invoke the message of a deity, whilst prophets receive it spontaneously, albeit an audible word, a dream or a vision. Although this sharp distinction is no longer tenable, it is certainly informative to examine briefly the different means of inductive and noninductive measures of divination.

\section{Inductive divination}

Inductive divination was common in the Ancient Near East, but only vaguely attested to in the Hebrew Bible, albeit not too favourably. ${ }^{6}$ This form of divination requires rather specialised knowledge and technical operations, which range from astrology, oil omens and birth omens to extispicy and necromancy (see Cryer 1994:141-181 for a detailed discussion). Abnormal appearances in the phases of the heavenly bodies, abnormalities in the births of animals or humans, or in the intestines of ritually slaughtered animals, all served as media by which the gods disclosed some important message to earthly beings. Also, the colour or motion of oil poured upon water could be a significant indication of events (almost like reading tea leaves!), or otherwise the diviner could look at the direction of smoke from an incense burner. These forms of divination required special training, skills and expert knowledge.

A further distinction is drawn between omnia oblativa and omnia impetrativa (Cryer 1994:141). The former - omnia oblativa - refers to phenomena that simply present themselves, such as a lunar eclipse, or, more ominously, birth defects in humans or animals. The latter - omnia impetrativa - are omens that call for some provocation, such as the slaughtering of an animal and reading the signs in its intestines. In the Assyrian period, five professional disciplines were distinguished: țupšarru (scribe,

6.Saul, consulting the witch of Endor (1 Sm 28) is an example of necromancy. 
or celestial diviner), bārû (haruspex), āšipu (exorcist), aŝิ (physician) and kalû (lamentation chanter). An expert in one or more of these disciplines was called ummânu (a scholar). They received an intense training at the scribal schools in the main temples of the major cities of Assyria or Babylonia (De Jong 2007:316) - perhaps analogous to tertiary education nowadays. With their knowledge of the supernatural and their learning, these scholars were able to read the signs, report omens to the king, perform rituals, chants, extispicy, apply medicine and so forth, in order to see, as well as to avert, danger. Their skills were so well respected that they were regarded as successors of the apkallu - those mythical antediluvian sages who imparted wisdom to all Mesopotamian kings.

\section{Non-inductive divination}

Non-inductive divination refers to the spontaneous revelation of divine messages to the recipient, that is, the prophet, which is more similar to the kind of prophecy of the Hebrew Bible (Malamat 1995:52). These are first-hand, first-person disclosures from the deity to the prophet (De Jong 2007:182), devoid of mantic or magic mechanisms, and could occur in the form of audible verbal oracles, dreams, or visions. In other words, the prophet is a passive recipient who did not do anything to provoke the oracle - it would come spontaneously, even unexpectedly. The initiative comes from the side of the divine, without request or invocation from the human side. Consequently, it is the god/ goddess who entrusts the prophet with a mission to transmit the message - asked for or not - to authorities who may or may not be impressed by what is disclosed. Prophetic manifestations of non-inductive nature are often accompanied by an ecstatic component in which the prophet experiences a different state of consciousness, exhibits frenzied behaviour, or goes into a trance (Malamat 1995:52). Peculiar gestures and utterances would serve to confirm contact with the supernatural world where the prophet can hear and see things ordinary mortals cannot. At times, there appears to be a complete loss of senses, where the prophet loses self-control and where speech is unintelligible and incoherent (Van der Toorn 2000:224).?

Amongst these prophets the following designations are common (cf. Huffmon 2003:119-122; Nissinen 2003a:6; Malamat 1995:56):

- $m u b b \hat{u}(m)$ (Babylonian), mabbû (Assyrian), with their feminine counterparts, mubbūtu(m), mabbūtu. These 'titles' are derived from the root mabĥ ('to become crazy, go into a frenzy') and refer to someone who reaches an altered state of consciousness whereupon they receive and transmit divine words.

- āpilum /āpiltum (fem), which is attested at Mari derived from the root apālu, which means 'to answer'. It is not quite clear whether a $m u b b \hat{u}(m)$ differed from an apilum, except that the former apparently had to remain at the temple to which they were affiliated, while the latter could travel from place to place. On occasion the âpilu formed bands and acted in consort (Malamat 1995:65).

- qammatum, which is attested at both Mari and Assyria/ Babylonia. The meaning of this designation is unclear, it may simply refer to the particular hairstyle of the cultic functionary; qabbātum ${ }^{8}$ may also have bearing on the Akkadian verb qabu, which means 'to speak'.

- $\quad n a b \hat{u}$, which may be related to the $n \bar{a} b \hat{\imath}$ ' of the Hebrew Bible.

- $\quad \operatorname{assinu}(m)$, which was prominent especially during the first millennium cult of the goddess Ištar (Fleming 2004:52); earlier at Mari, the assinum was in the service of the goddess Annunitum. This was a male performer who played female roles; however, the resulting ambiguity with regards to gender seems to have served the purpose to create a 7.Malamat (1995:52) is not clear on this matter, because for him 'prophets always
appear sober and purposeful in thought'. However, this remark may rather have bearing on the textual/scibal evidence than on the utterance itself!

8.In cuneiform script, the consonants ' $m$ ' and ' $b$ ' are often interchangeable. 'genderless person' who passed the message of a deity on to the king, regardless of gender or larger ritual role.

- raggimu / raggintu (fem) - in Neo Assyrian sources the term mabbû was replaced by raggimu apparently derived from the verb ragāmu ('to shout, to proclaim').

- Šabrû, which is also indicated as a counterpart to raggimu, probably referring to someone who is able to receive message dreams (De Jong 2007:314). Obviously not all dreams were considered as prophecy: an authentic prophetic dream would contain a divine message (Nissinen 2004:22) of particular importance.

The above exposition immediately raises the issue of gender. Most of the prophetic designations appear to have a feminine counterpart and, in fact, prophecy by women was not an uncommon phenomenon in the Ancient Near East. At the Mari court of Zimri-Lim, a large proportion of prophecies were delivered by women (Malamat 1995:63) and also documents uncovered at the temple of Ištar at Arbela reveal many prophecies made by prophetesses (see De Jong 2007:294-297). With regards to the latter, it may be noted that Ištar was a goddess and served by many women, also that she was a goddess of war and many prophecies documented at the Arbela-temple relate to matters of war. But, given the fact that there were other kinds of prophecy by women as well, one may safely conclude that prophetesses played an important role in Ancient Near Eastern prophecy and that their oracles were taken seriously. ${ }^{9}$

A further question that is still much debated is whether a distinction can be drawn between the so-called 'court' prophets and the 'lay' or 'free charismatic' prophets. Malamat (1995:6263) interprets a number of prophetic documents at Mari as emanating from 'lay' prophecies. The verb tebu ('to arise') is decisive in this matter: messages delivered by accredited prophets are all preceded by some form of this verb (tebu) (Malamat 1995:64) and pertain to a prophet who receives a direct revelation, 'arises' in a temple and delivers a message whilst fully conscious. Weinfeld (1995:35-36) also refers to Mari texts in which a prophet rises (itbe) or stands on his feet for hearing or delivering the word of a deity.

The lay prophets were also dreamers - apparently the accredited prophets did not dream (cf. Malamat 1995:64). Lay prophets received their revelations through dreams, which often called for some interpretation, whilst accredited prophets were at their full senses when receiving and delivering an oracle. Huffmon (2003:122) agrees and relates an incident where private persons without a specific prophetic designation, either become ecstatic (in a temple of Annunitum) and deliver an oracle, or report dream messages. Also Fleming (2004:54) expresses some doubt as to whether all prophets were permanently attached to a temple. It may be possible that some temple personnel were employed at the temple on a more permanent base than others. For example, the permanent temple personnel would have been responsible for the daily cleaning and maintenance chores, whereas others, such as prophets, wrestlers, singers and musicians would perform only on occasion.

However, more recently, De Jong (2007:297) is of the opinion that all prophets bearing any of the prophetic designations were permanently part of the temple personnel who lived and worked there and also received food or other form of compensation. Nissinen (2004:23) also argues that the 'often made dichotomy between free charismatic prophets and so-called cultic or court prophets' can no longer be upheld and is based on the biblical portrayal of, especially, Amos (8:14-15) against Amaziah at the court of King Jeroboam of Israel. This matter is still open to debate.

However, within the rigid hierarchal social system of the ancient world, it is unlikely that anyone in royal circles or the

9.For the rest of this article, the designation 'prophet/he/his' includes 'prophetess/she/ her'. 
intermediaries who reported prophetic oracles would pay heed to an outsider who claimed to be a prophet without having credentials of any sort.

Prophets mostly delivered their oracles at temples, usually in the presence of a witness - one or more - who was responsible for the interpretation and transmission of the message to the one for whom it was intended. The prophet would stand in front of a statue or symbol of the deity, functioning as its mouth whilst delivering the oracle (see Van der Toorn 2000:221-224). However, there were exceptions; oracles may also have been delivered in public spaces, such as the city gate. For example, at the Saggartum gate of the city of Terqa, the elders were called together by an ecstatic from the Dagan Temple. Here they were to witness how he devoured a living lamb before their eyes. This would be an act, symbolic of an epidemic (ukultum, 'devouring') among the cattle. Apparently the sacred property of the god had been distrainted by some evildoer. The symbolic gesture by the prophet urges that the property of the deity be returned and the culprit banned from the city (see Van der Toorn 2000:227; cf. De Jong 2007:311). Another example - although not one that is conclusive in the matter - concerns Esarhaddon, who, on his way to Egypt, receives encouragement by a prophet from Sîn of Haran. It is unclear whether the message was delivered before his departure or during the course of his travels, but it leaves the possibility open that prophets could have joined military campaigns as part of the divinatory staff (De Jong 2007:301). Decisive evidence, however, is lacking and, furthermore, it is highly unlikely that prophetesses would accompany such campaigns.

\section{The relationship between divination and prophecy}

Instead of making the sharp distinction between inductive divination and non-inductive prophecy, scholars nowadays are of the opinion that both are branches of the same tree and stand in a complementary relationship to each other, rather than being in conflict (De Jong 2007:313; Nissinen 2004:21). Both forms of divination were practiced side by side and shared the same ideological basis, namely that gods knew what humans did not and they wished to convey this knowledge to those on earth. Decisions made in heaven directly affected the earthly world and, as the extant sources reveal, these often pertained to the so-called Herrschaftswissen - the affairs of the ruler and the state, which, of course, had implications for everybody. Thus, far from being mutually exclusive, diviners and prophets worked together to serve the king and secure the well-being of the nation. The message was so much more important than the mode of transmission.

The main difference between prophets and diviners seems to lie in their degree of scholarly training. The diviners were academics (De Jong 2007:317) who received an intensive form of education and were experts in their field. They were also of the literate few in the society, they emanated from guilds of trained diviners and, more often than not, they stemmed from select families. While women were common - even prominent - within the prophetic sphere, none were found among the scholars (De Jong 2007:318; Nissinen 2004:23)

It cannot be stated conclusively that prophets received no training at all ${ }^{10}$ - probably they had to undergo some form of preparation - however, this would hardly match the high degree of the scholars' scribal education (De Jong 2007:316). As far as can be gathered, the prophets were mostly illiterate and their oracles had to be recorded, if not interpreted by the more learned scribes.

10.Although the Gilgameš Epic is not a prophetic text, the trip to the Cedar Forest (Tablet IV) describes certain preparations that Gilgameš and Enkidu perform in order to provoke a dream omen where they pitch camp for the night. This may order to provoke a dream omen where they pitch camp for the night. This may
suggest that the dream-prophets performed similar rituals in an effort to receive a dream.
A further observation is significant. At Mari, prophets worked mainly in temples together with other temple personnel. Diviners, on the other hand, were primarily the servants of the king and served in the royal court. Although prophets were respected for their ability to act as the 'mouthpiece of a god', the real political power lay in the hands of the diviners (Fleming 2004:45). This was also the case in 7th-century BCE Mesopotamia. During the time of the Neo-Assyrian Empire, specifically during the reigns of Esarhaddon and Ashurbanipal, scholars were employed directly by the royal court, whereas the prophets operated in a temple environment (De Jong 2007:317). It seems that diviners enjoyed some status above that of the prophets, as they were closer to the king and other royal functionaries. And although, as has been stated above, diviners and prophets were not in conflict with each other, competition among the scholarly disciplines was intense. Diviners, being closer to the king, were also dependent on his favours and were continuously competing to be in his good books. Prophets, on the other hand, stood at a distance. Of course, their fate was bound to the goodwill of the king and, of course, they were also dependent on his favours, but the prophets, unlike the diviners, were not employed by the king: they were employed by the gods. Their first and foremost responsibility was to act 'as the mouthpiece of the gods'.

\section{PROPHETIC CRITICISM}

Prophecy in the Hebrew Bible is often distinguished from prophecy in the rest of the ancient world by the courage of the former to criticise the status quo. Once again this argument takes Amos as an example: the biblical prophets challenged the king and the government and dared to speak out against social injustices and exploitation of the poor, whereas the prophets of the nations supported the king regardlessly. Therefore the Heilsprophetie of the Ancient Near East is considered to stand in sharp contrast to the Unheilsprophetie of the Hebrew Bible (Nissinen 2003b:1-2). However, this is yet another distinction that is no longer tenable.

The duties and responsibilities of an Ancient Near Eastern king were not much different from those of the kings of Israel/Judah and, more or less, the same demands that Yahweh imposed on the monarchies of the two kingdoms were expected by the gods of the nations from their kings. In the first place, a king had to fulfil certain obligations towards the gods. He had to look after the maintenance of the temples in order to secure the continuation of the cults of the various gods (Nissinen 2003b:4). ${ }^{11}$ After all, the temple was the sphere of intersection between the heavenly and earthly realms, the place where humans and deities met and communicated with each other. Inside the temple the gods disclosed their wishes and revealed knowledge from above by means of their prophets and prophetesses.

However, not only words of peace and comfort were spoken! Texts from both Mari and Arbela contain divine criticism against the king who had neglected to care properly for the temple (see Nissinen 2003b:5-6). In both cases the goddesses of the temples especially, remind the king of certain favours they had done for him - such as offering up the enemy into his hands - yet the king had done nothing in return.

Besides showing respect to the gods and keeping their dwelling in shape, a king also had obligations towards his subjects. He was to be to them as a shepherd is to his sheep; he was expected to rule with justice and protect the interests of the poor, the widow and the orphan (De Jong 2007:309; Nissinen 2003b:14). The gods make these expectations clear in the messages that they convey to the king by means of their prophets. For example, Zimri-Lim is reminded that it is by the grace of Adad that he has been enthroned as the legitimate heir to the house of his fathers.

11. This was extremely important in a polytheistic world (see Huffmon 2003:116-131). Apparently, prophets received dreams or omens from various deities, depending
on a situation (e.g. an encouragement for the king at war as opposed to instructions on a situation (e.g. an encouragement 
He also received (divine) weapons with which to contain the primeval powers of chaos. In return, the deity expects that he rules his subjects with righteousness, but also that he pays heed to the divine oracles that may be disclosed by the prophets. This would be a token of his obedience and would result in even more blessings. However, if the conditions are not met, some form of punishment would follow (see Nissinen 2003b:19-21).

Furthermore, a king could certainly not do simply as he pleased. King Hammurabi of Babylon wished to establish good relationships with the ruler of Elam, and used (or abused!) the temple treasures of Marduk for this purpose. Helpless and furious at the decisions of the government of their time, the prophets within the temple community proclaimed that, ironically, not Hammurabi, but his protégé, Išme-Dagan, would pay dearly (De Jong 2007:310-311; Van der Toorn 2000:228). Thus, there was no question about unconditional support on the part of the gods: do ut des was the guiding principle. Yes, the gods would bestow honour and glory upon the king, but expected something in return (De Jong 2007:308). If the king failed to perform, the prophets stepped forward to remind him about his neglect and to warn him about the wrath of the gods. ${ }^{12}$

Matters could become even worse when the anger of the gods was not directed at the king alone - his misbehaviour could endanger a whole nation. The Esarhaddon inscriptions mention the reasons for the destruction of Babylon: the order of the day were oppression of the weak, acceptance of bribes, theft of property, children who show disrespect for parents. Therefore, the god (Enlil or Marduk) became angry and decided to overwhelm the land and destroy the people (Weinfeld 1995:47-48). In this case, a prophecy of encouragement has been be turned upside down and directed against the king in favour of his adversaries. The patron god of the city actually chose the side of the enemy.

Thus, in order to serve the interests of both the state and the nation, the prophets all over the Ancient Near East dared to criticise the behaviour of the king. Although this was not encouraged ${ }^{13}$ prophets raised their voices in the service of a greater cause, 'for the benefit of social and cosmic stability' (De Jong 2007:313; cf. Nissinen 2003b:30). After all, the relationship between the gods and the king determined the welfare (or lack thereof) of the community, thus it had to be a good one in order to have a favourable outcome. The prophets served as a 'barometer' of this relationship and part of their job was to detect flaws that might endanger a whole people and lead to disastrous consequences.

How did they dare to voice their criticism? Perhaps the answer lies in the fact that they were not part of the close inner circle at the royal court. This was where the diviners, the scholars, belonged. They were the immediate employees of the king, they had to vie for his favours and had to be careful not to anger those in control. Prophets, on the other hand, stood at a certain distance and were slightly further removed where they lived and worked at the temples. The prophets were the employees of the gods and their first responsibility was towards the deities (De Jong 2007:313). As mouthpieces of the deities, it was their duty to speak on their (the deities') behalf. This could ask from them to criticise the status quo (Nissinen 2003b:30) and go against the wishes of the king, yet they could dare to do so, because, although the king was powerful, even he stood under the authority of the gods. After all, the prosperity of the king and the whole nation was dependent on obedience towards the deities and acting out divine will. Prophetic criticism in the ancient world was not an uncommon phenomenon as is often assumed.

12.See Nissinen (2003b:4-23) for more examples of texts from both Mari and Nineveh pertaining to obligations towards the cult and social justice which the king had neglected and against which the prophets/prophetesses announce their dismay.

13.For example, the Esarhaddon vasal-treaties, which demand unconditional loyalty to the Crown Prince Ashurbanipal (cf. Nissinen 2003b:24).
This is not to say the prophets rejected the monarchy or rejoiced in the downfall of the nation of which they were a part. Almost always, the king was given an opportunity to correct his wrongdoings (De Jong 2007:311-312). Prophecies of doom were thus not final - the king was given a chance to listen to the prophet, to abandon his devious ways and, thereby, to avert danger. The prophet only did his job by revealing that the misconduct of a king would result in some disaster. The prophet, by daring to oppose the king, was actually protecting a whole nation.

Indeed, not all disasters struck and sometimes dangers were warded off. However, this did not imply that the prophecy was false. If the predicted catastrophe did not happen, it simply indicated that the king paid heed to the prophetic oracle and complied to the will of the gods. The angry gods would thus be appeased and change their minds.

\section{THE WORDS OF THE GODS?}

What is meant by prophets, prophecy and prophetism in the 21st century? In reflecting on this question, the following observations from the Ancient Near East should be kept in mind.

\section{A message from a deity}

All prophets claimed that they received a message from a deity. This was the very essence of prophecy. But how could this assumption be verified? Who could check it? The original prophetic oracle was something that happened only between the prophet and the deity: even if witnesses were present when the prophet delivered the oracle, they did not see or heard what the prophet did (Nissinen 2000:239). Only the prophet was aware of the appearance or voice of a deity, all others were second-hand recipients.

Today, one may ask: Who are the prophets and from whence did their messages come? Indeed, someone claiming to hear the voice of God is soon rushed to the consulting rooms of a psychiatrist, where they are given pills to make the voice go away!

\section{A community of believers}

Only a religious community who believes in some sort of involvement between humans and the divine, would take the words of someone who proclaims to be a prophet seriously. The message of a prophet is credible in the sense that it is believed to come from some deity or another. This happens if everybody believes in the same G/god(esse)s. Prophetism, that is, belief in the disclosure of divine will only makes sense in a faith-based society (Nissinen 2004:23).

In democratic, postmodern, post-religious societies, one has to ask: What makes a prophetic message credible in pluralistic, multi-religious or a-religious circumstances?

\section{The interpreters}

In the beginning of this article I have indicated that some time elapsed between the first oral utterance of the oracle and its later textual record - this means that the original oracle underwent several processes of transmission (see the section headed 'Sources for prophetism in the Ancient Near East' above). One only has to think of the children's game 'telephone', in which children sit in a circle or a row, the first person whispers something in the next one's ear, who repeats it to the next and so forth. The last person has to say out loud what she has heard, often resulting in much laughter about how the original had changed. But, if an original message can be distorted within a couple of minutes, what may happen after years, or even centuries?

However, the degree of time between utterance and transcription is not the only issue. The communication process of 'sender- 
message,-recipient' happens to be rather complex with regards to prophecy. A deity was the 'sender', the 'message' was from divine origin the 'recipient' was the prophet, but he was not the addressee and, often, he was unable to interpret the message. Most of the prophets belonged to the illiterate part of the society and more often than not did not have direct access to the king to whom the oracle was addressed in the first place. Another intermediary was required, someone who was able to read and write and, by nature, someone who was closer to the royal court (Nissinen 2000:240-241; Van der Toorn 2000:228-229). Thus, between the prophet and the addressee stand the interpreters of the message, the scribes. They were the authorities who controlled prophetic activities and, as intermediaries, they were the ones who decided what was recorded and what was ignored. They did not render the prophetic oracles verbatim or objectively for the sake of submitting a clinical report, because this was not their interest. Furthermore, they were the children of their time, in that matters of style, literary conventions and perhaps even personal interests may have influenced the final shaping of the oracles on record. Also, as has been indicated, some of these are purely literary inventions and probably bear no relation to real prophetic oracles at all (see the section headed 'The Mari documents' above).

The ipsissima verba - the actual words - barely survived the moment of utterance. The words of the prophets are as lost as the historical prophets themselves- forever (Van der Toorn 2000:219, 230). Put very crudely, the words of the prophet are not the words of the prophet, but the twisted version of some scribe with a hidden agenda. Even though this statement may be an exaggeration, the truth of the matter is that prophetic messages, as recorded in texts, are subjected to much uncertainty. The documented record hardly ever conveys the true words of a prophet: prophecy, as it appears in texts, is always, without an exception, a hermeneutical exercise - an interpretation. This is the case with prophecy in the Ancient Near East as well as in the Holy Scriptures of all religions.

\section{CONCLUSION}

Can we infer anything about prophetic witness from the texts at our disposal? If we wish to make direct inferences, the answer is 'no'. Through the texts we cannot find a prophet nor prophetic oracles, we can only find interpretations. The prophet is gone and all we are left with is the testimony of a scribe whose main interest was certainly not to write a verbatim report on the spoken words of the prophet.

Yet this realisation should not leave us discouraged. Who were the scribes? They were the intellectuals of their time and they were also astute observers. They found themselves in a particular historical situation in which many complex issues caused a lot of trouble. With their intellect and skill, they responded to the questions in their community. These intellectuals were not the first-hand recipients of a prophetic message, but they were the interpreters of the signs of their time. They managed to inspire, to encourage, but also to criticise. They were sensitive enough to hear a chain of voices that came to them through many ages and creative enough to apply striking chords to old songs and make them resound powerfully in each new situation.

On this note, I conclude my article and carefully rephrase what I understand prophecy to be, that is, an ongoing intellectual grappling with reality.

\section{REFERENCES}

Cancik-Korchbaum, E., 2003, 'Prophetismus und Divination - Ein Blick Auf Die Keischriften Quellen' [Prophetism and Divination - A View on the Cuneiform Sources], in M. Köchert \& M. Nissinen (Hrsg.), Propheten in Mari, Assyrien und Israel, pp. 33-53, Vandenhoeck \& Ruprecht, Göttingen.

Cryer, F.H., 1994, Divination in Ancient Near Israel and its Near Eastern environment. A socio-historical investigation, JSOT Press, Sheffield.

De Jong, M.J., 2007, Isaiah among the Ancient Near Eastern prophets. A comparative study of the Isaiah tradition and the Neo-Assyrian prophecies, Brill, Leiden.

Fleming, D.E., 2004. 'Prophets and temple personnel in the Mari archives', in L.L. Grabbe \& A.O. Bellis (eds.), The priests in the prophets. The portrayal of priests, prophets and other religious specialists in the latter prophets, pp. 44-64, T\&T Clark International, London.

Gordon, R.P., 1995, 'A story of two paradigm shifts', in R.P. Gordon (ed.), 'This place is too small for us': The Israelite prophets in recent scholarship, pp. 3-26, Eisenbrauns, Winona Lake.

Huffmon, H.B., 2003, 'The one and the many: Prophets and deities in the Ancient Near East', in M. Köchert \& M. Nissinen (Hrsg.), Propheten in Mari, Assyrien und Israel, pp. 116-131, Vandenhoeck \& Ruprecht, Göttingen.

Kratz, R.G., 2006, 'Prophet', in A. Berlejung \& C. Frevel (Hrsg.), Handbuch theologischer Grundbegriffe zum Alten und Neuen Testament, pp. 343-345, Wissenschafliche Buchgesellschaft, Darmstadt.

Malamat, A., 1995, 'Prophecy in Mari', in R.P. Gordon (ed.), 'This place is too small for us': The Israelite prophets in recent scholarship, pp. 50-73, Eisenbrauns, Winona Lake.

Malamat, A., 2000, 'Spoken, written quoted and invented', in E. Ben Zvi \& M.H. Floyd (eds.), Writings and speech in Israelite and Ancient Near Eastern prophecy, pp. 235-271, Society of Biblical Literature, Atlanta.

Nissinen, M., 2003a, Writings from the ancient world. Prophets and prophecy in the Ancient Near East, in P. Machininst (ed.) and contributions by C.L. Seow \& R.K. Ritner, Society of Biblical Literature, Atlanta.

Nissinen, M., 2003b, 'Das kritische Potential in der altorientalischen Propheti' [The Critical Potential in Ancient Near Eastern Prophecyl, in M. Köckert \& M. Nissinen (Hrsg.), Propheten in Mari, Assyrien und Israel, pp. 1-32, Vandenhoeck \& Ruprecht, Gottingen.

Nissinen, M., 2004, 'What is prophecy? An Ancient Near Eastern perspective', in J. Kaltner \& L. Stulman (eds.), Inspired speech. Prophecy in the Ancient Near East. Essays in Honor of Herbert B. Huffmon, pp. 17-37, T\&T Clark International, London.

Van der Toorn, K., 2000, 'From the oral to the written. The case of old Babylonian prophecy', in E. Ben Zvi \& M.H. Floyd (eds.), Writings and speech in Israelite and Ancient Near Eastern prophecy, pp. 219-314, Society of Biblical Literature, Atlanta.

Weinfeld, M., 1995, 'Ancient Near Eastern prophetic literature', in R.P. Gordon (ed.), 'This place is too small for us': The Israelite prophets in recent scholarship, pp. 32-49, Eisenbrauns, Winona Lake. 